\title{
Implementation of Sustainable Architec- ture to Support The Efforts to Achieve Green City
}

\author{
Gatut Wicaksono GW ${ }^{1}$, Winny Astuti ${ }^{2}$, and Titis \\ Srimuda Pitana ${ }^{3}$ \\ ${ }^{1}$ Environmental Science, Graduate Program, Sebelas Maret University, \\ Surakarta \\ ${ }^{2}$ Area and Urban Planning Department, Engineering Faculty, Sebelas Ma- \\ ret University, Surakarta \\ ${ }^{3}$ Architecture Department, Enginering Faculty, Sebelas Maret University, \\ Surakarta
}

\author{
Article History \\ Received : 07 April 2017 \\ Accepted : 24 May 2017 \\ Published: 30 Oktober 2017
}

\begin{abstract}
Recently, the phenomenon of climate change effect has been clearly seen. Green city as concept of development have been initiated in several countries in the world with the expectation to contribute to the mitigation of global warming impact. Green City is the city that prioritizes the balance of bio-ecosystem with the environment to create comfortableness for the city residents and visitors (Yunus, 2012). Attributes of green city is related with the concept of sustainable architecture as the effort to minimize the negative impact towards the environment to address environmental problems caused by architectural complications.
\end{abstract}

This paper focuses on the implementation of sustainable architecture in supporting the effort to achieve green city. This research conducted exploration in the aspect of planning and implementation that accommodate the concept of green city in architectural aspect based on the city planning in Surakarta City. This research is conducted in several locations in Surakarta City such as Kampung Iklim Sekip Kadipiro, Selasar Budaya Kampung Jagalan, and Mojosongo. The three locations develop the planning and implementation of design with the principles of low cost, simple technology and low impact to the environment. Those efforts support the program to realize green city through sustainable architecture implemented in the building and simple supporting element of environment with low cost.

Keywords: green city, sustainable architecture, eco-friendly, climate change.

\section{Introduction}

Sustainable development is the development that may fulfill the need of current society without neglecting the ability kof future generation to fulfill their need. As a process of change in which the utilization of resources, orientation of investment and development, and institutional change are always in balance and synergy to enhance present and future po-

Correspondence: Gatut Wicaksono GW.

Environmental Science, Graduate Program, Sebelas Maret University, Surakarta

E-mail: wicaksono_gatut@yahoo.com tentials to fulfill the need and aspiration of human beings (Brundtland, 1999).To keep the balance of environment in the development of city buildings, one of the concept that can be used is the green city concept. This concept promoted development of city in harmony with nature keeping the balance of development and preservation of environment. From the aspect of green city such as green buildings, sustainable architecture becomes one of the solution to reduce environmental problems.

One of the definitions of sustainable architecture is architecture that fulfills recent needs 
Implementation of Sustainable Architecture to Support

The Efforts to Achieve Green City

Gatut Wicaksono GW, Winny Astuti, and Titis Srimuda

Pitana without harming the ability of future generation to fulfill their needs. The needs of every community are different from one another and the need of one area is different from another area. The best party who decides the need of the society is the society itself (Steele, 1997). Urban planning in relation to sustainable architecture is reflected in the regulation related to the buildings that accommodate the concept of green city. Some aspects of the green city concept are efficiency of energy, space or land, material, technology, and waste management. One of the aspect is related with the utilization of land as the important part in development planning. The implementation of land use can be realized by effective and efficient use of land. This article will discuss about sustainable architecture in supporting the effort to achieve green city using design innovation with low cost, simple technology, and low impact to the environment in line with the urban planning that accommodate the concept of green city.

\section{Green City Concept as Sustainable City Development}

The development of social and economic activities and the increase of production, consumption, and life style have caused some negative impacts to the environment. Some of the impacts are pollution and the decrease of renewable resources that requires ecological approach to improve the quality of environment in the city. The success of sustainable development is not only depending on the economic sector but it also requires the intervention from the stakeholders especially the government of the city to implement sustainable development to achieve the goal of wealth distribution. Thus, sustainable development should be oriented to develop green city with good living quality and conducive environmental condition.

Sustainable development is directly integrated with environmental, economic, and social sustainability. The following figure shows how the integration of environmental, economic, and social sustainability can contribute to wealth for human beings. In the application of sustainable development, the three elements should work simultaneously in balance (Priyoga, 2010).

Figure 1.Integration of Environment, Economy, and Social (Source:Hui, 2002).

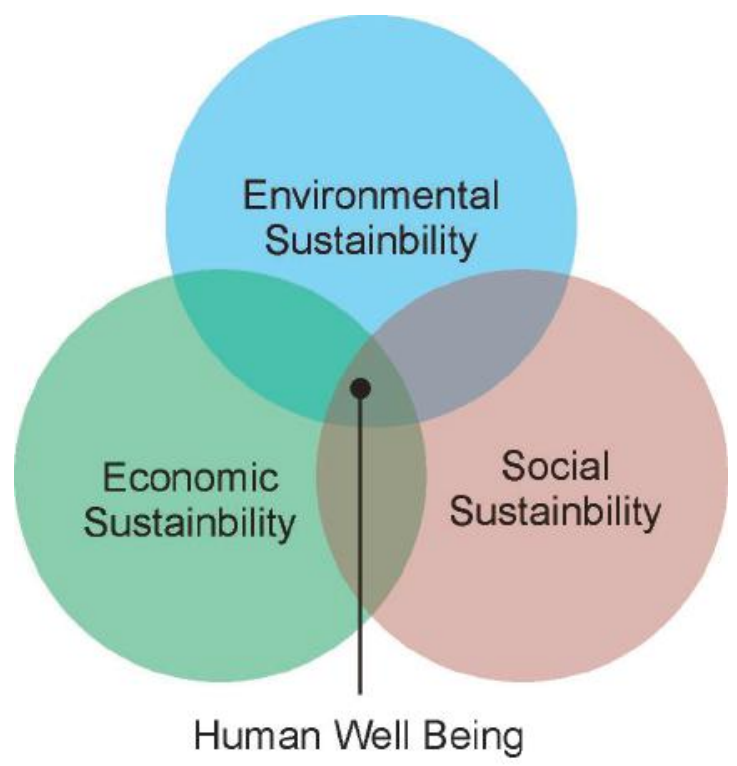

tainable city that are harmonious with the nature is also known as ecological city or healthy city. This means that there is balance between the building and development of city with the environment preservation. Healthy city is also a condition in which a city is safe, comfortable, clean, and healthy for residence by optimizing the social economic potential of the society through community empowerment forum facilitated by related sector that is synchronized with the urban planning. In addition, other definition of green city is eco-friendly city that uses water and energy effectively and efficiently, reduces waste, implements integrated transportation system, ensures the environmental health, synergizes the artificial and natural environment, based on the planning and design of city that prioritize the principle of sustainable development (Wildsmith, 2009).

The other definition of green city is city that is designed by considering the impacts towards the environment with the residents who have the awareness to minimize the use of energy, water, and food as well as to minimize waste, 
air and water pollution (Register, 1987). Meanwhile, the aspect of Green City are (Linfield and Steinberg, 2012) : development of strategies for layout and technology of green city, energy strategy for green city, transportation for green city, water management for the future of green city, waste management of green city.

To realize the green city, collaboration between all parties is necessary. The awareness of the society and the city government must put emphasis on the need to develop city by considering ecological condition and to minimize negative impacts of city development.

\section{Sustainable Development in the Concept of Green City}

The climate change influences the tendency of change in the development paradigm. The top change in development in the 1900s had the orientation to provide building comfortableness designed by individual in active building design, which gradually directed to sustainable development referring to passive building design. Roaf stated that the dynamics of a more ecofriendly development has reached the peak in the year 2000s. The concept of sustainable development progressed rapidly because it is relevant with the condition and situation of the degraded environment, which lead to the establishment of eco-friendly concept (Yuliani, 2005).

Sustainable architecture is an applied concept in architecture that preserve the natural resources to be available for longer time in relation to the vital potential age of natural resource and ecological environment of human being (Wikipedia, 2014). Sustainability architecture is part of sustainability development. "Sustainable development is development which meets the needs of the present without compromising the ability of future generation to meet their own needs" (Brundtland, 1987). Environmental architecture that contains five basic principle i.e. Interior environmental health, efficiency of energy use, reduction of harmful materials to environment, site, and architectu- ral form management that is responsive to environment and climate, and design that boost the improvement of physical quality of environment, spiritualism, and history (Fisher, 2002).

Some institution has conducted examination on the implementation of sustainable architecture in the reality of building and environment. One of the indicators for measurement is developed by the Leadership in Energy and Environment Design (LEED). LEED System is developed by the U.S. Green Building Council (USGBC) in the year 2000. Fisher's theory on environmental architecture and the indicator of green architecture from LEED was adapted from some factors such as Site design; water efficiency; energy and atmosphere; materials and resource protection; indoor environmental quality; locations and linkage; innovativeness and design/construction process; awareness and education (Primadella, 2014). Those factors are part of the green city concept.

\section{Implementation of Sustainable Ar- chitecture in Effective Technology Based on the Urban Planning}

The development of a city cannot be separated by the role of architecture and supporting regulation of a city (Eryudawan, 2016 ). The management of a city can be considered failed if the city layout and the architecture are not aligned, operating individually, or interpreted differently. The city layout can be considered failed when it does not succeed to accommodate the aspiration the society about how the city should be developed. In addition, law enforcement to create order in the society is also crucial. The lawn can be enforced when it is based on the awareness of the society raised through dialogues with the government as the medium of education and to create harmony between the city layout and architecture in order to achieve sustainable space (Dyahunique, 2009).

The design of sustainable architecture concept should not be applied in sophisticated building only but also to simple building for people 
with limited income. Sustainable architecture according to the environmental aspects can be seen in following concept of green city:

1. The Development of city layout and technology through green planning and design, green open space, eco-friendly technology (green technology).

In green planning and design, design is based on planning and design of city that is responsive to the environment. The utilization of land as efficiency of space use includes followings: using land only as needed and not using the whole land for building, efficient, solid, and integrated use of land. Every zone or area has the specific allocation in making a building that should be obeyed such as Building Basic Coefficient, Floor Area Ratio, Building Matching Line, and Open Space.

The design of a house in Mojosongo location as the compensation for relocating houses in the riverbank of Bengawan Solo has tried to accommodate the concept sustainable architecture with cost of construction adjusted with the ability of people with low income.

Figure 2. The concept of simple house design in Mojosongo Surakarta. (Source: Paryanto, 2015).

With limited land size of 4 meter $\times 10$

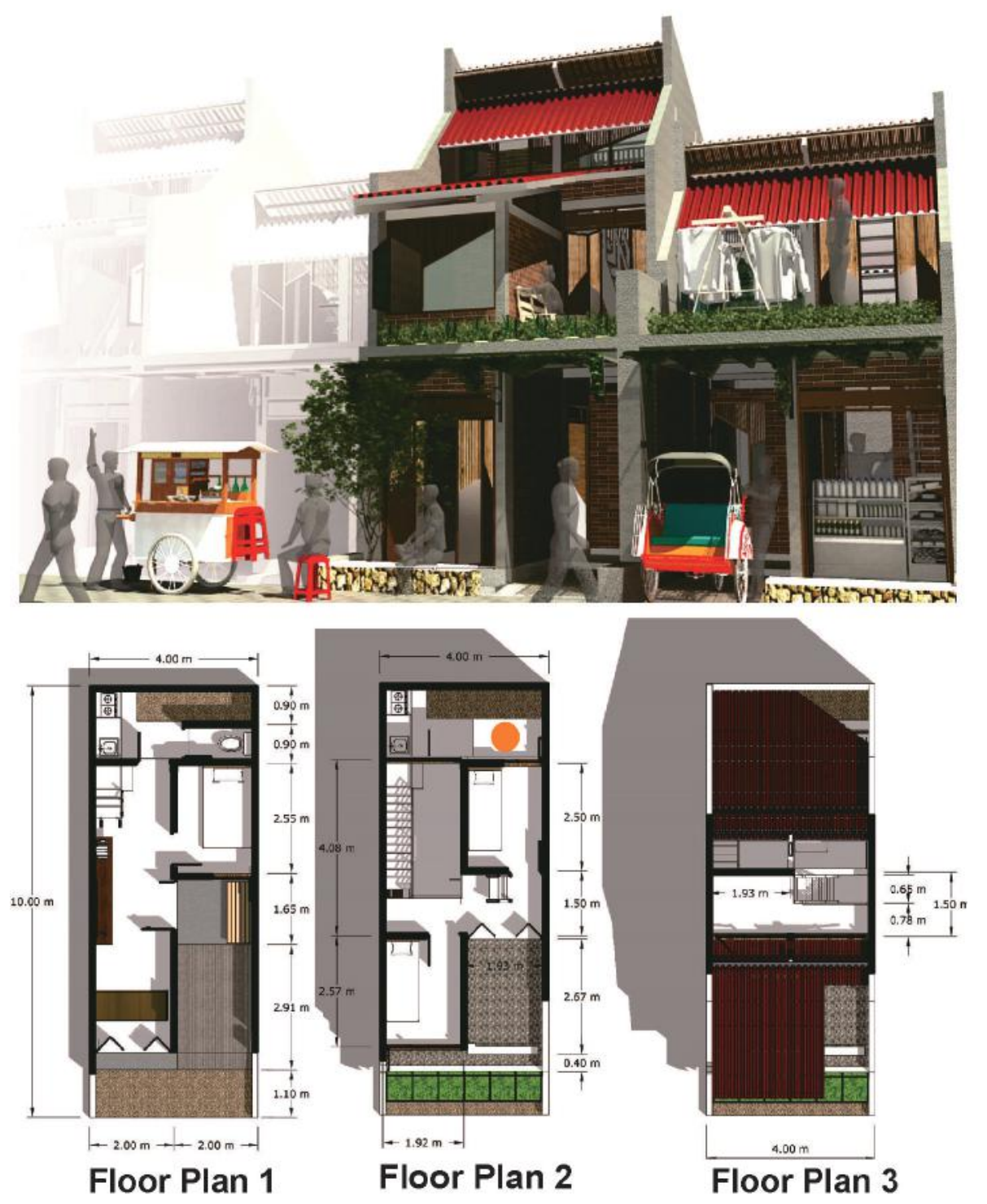

http://journal.uii.ac.id/index.php/jards 
meter, as the compensation of house relocation from the riverbank of Bengawan Solo, the design of the building has been adjusted with the city planning. Although the land is limited, the building still has open space.

2. In green open space, vegetation functions as climate regulator (temperature, humidity and the speed of the wind) and it is good for the scope of residential house site and for area scale. The availability of vegetation actually means the availability of green open space and the controller of water management.

The availability of open space and vegetation will provide oxygen and will flow it to the house to provide comfort. Vegetation on the roof of the house (green roof) can overcome sun radiation and make the house condition becomes cooler. The green element is identical with vegetation. By adding greening element not only in the landscape but also in the building such as roof garden, planting spreading vegetation in the wall of building and so on (Sukawi, 2011). The implementation of greening in the upper floor of a building is one of the way to accommodate open green space through the design of vegetation in the upper floor.

3. In green technology, the implementation of green technology can be done in the material of building as follows: utilizing used materials in the process of construction so there will be not building waste. For example, the used wood can be used for other part of the building, utilizing used material for constructing new building such as using old components such as using the remains of old building, using renewable material that can be produced in a short time, cheap, and open for innovation.

4. In green energy, the utilization of efficient and ecofriendly energy can be done by reducing non-renewable energy or using renewable alternative of energy. Other way is by utilizing the potential renewable such as wind energy, solar energy, and water energy to produce electricity for household and other building independently and optimization of those resources. The implementations of this for building are using sunlight for natural illumination maximally at the daytime to reduce the use of electricity and using the natural temperature controller to substitute artificial air conditioner.

Urban planning related to building is regulated in the local regulation number 8 year 2016 about building in the article 25 verse 2 about building design. It is stated that every room should use natural illumination and air conditioning whenever possible except the function of the building needs artificial illumination and air conditioner. Illumination and air conditioning refers the concept green building development.

5. In green water, urban planning about building has been regulated in the local regulation number 8 year 2016 article 49 verse 2 . This verse is related to rainwater drainage using water absorption system to the ground water in the house yard or it can be flown the absorption well before it is flown to the drainage channel in the environment. The increase of efficiency in the utilization and management of water resources could be done by conservation of water resources, covering of clean water access by implementing zero runoff concept, reusing used water, rain water harvesting, the increase soil ability to absorb waters, surface water management system in city and land quality improvement from water related disaster.

The management of rainwater has been 
developed in Kampung Iklim Sekip Kadipiro Surakarta using effective innovation by combining the plants shelter and water catcher pipes. This design has simple finishing but it is quite useful. Besides, biopore hole is also used in unlimited environment including personal land. Thus, optimization of biopore is expected to help maximum absorption of water.

Figure 3. Shelter of plants and raiwater saver in Proklim Sekip Kadipiro Surakarta (Source: Presentation from Kampung iklim Sekip Kadipiro, 2015)

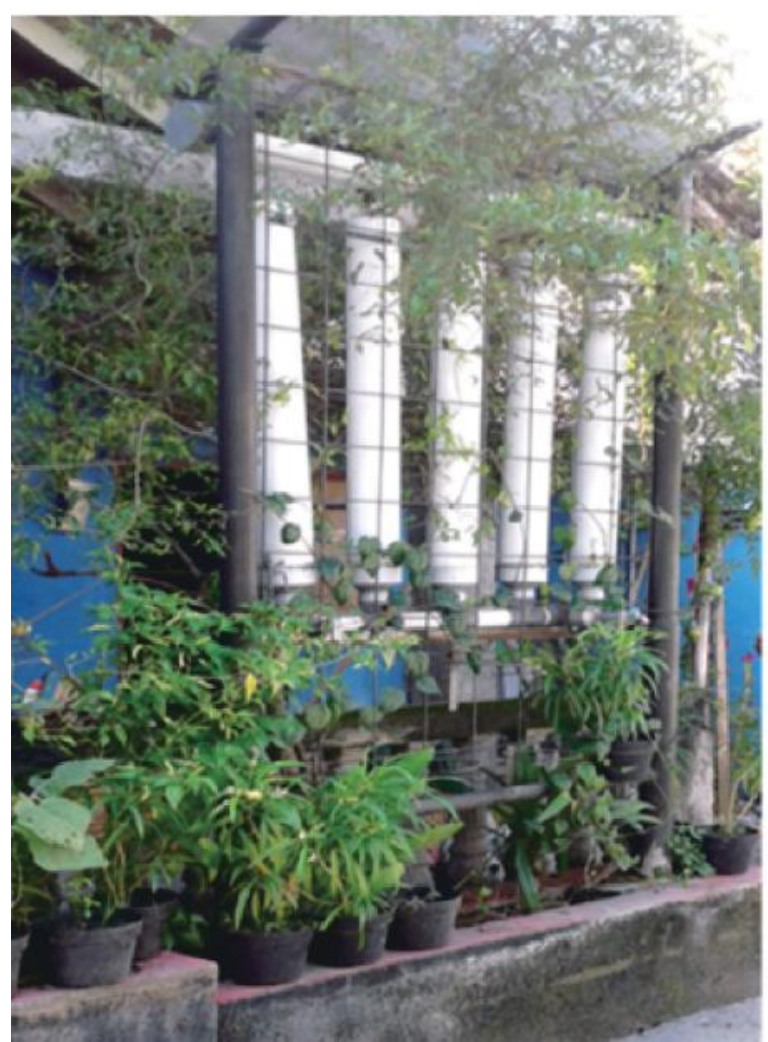

6. In waste management (green waste), urban planning related to building has been regulated in the local regulation number 8 year 2016 about construction of building in the article 50 verse 5 . The potential to reduce water can be done by recycling and or reusing the garbage. In this case, the implementations of waste or garbage management are as follows:

a). Making independent domestic waste management system and not burdening the city water flow system, b). Some innovative ways that can be done such as using organic waste decomposition system for natural biodegradation, making products that are easy to be decomposed in natural way.

The management of garbage in Gang Kali Kampar Selasar Kampung Budaya Jagalan Jebres Surakarta tried to combine the greening of plants pot, garbage composing, and biopore absorption point.

The innovation in the management of or-

\section{Rain water tank/reservior}

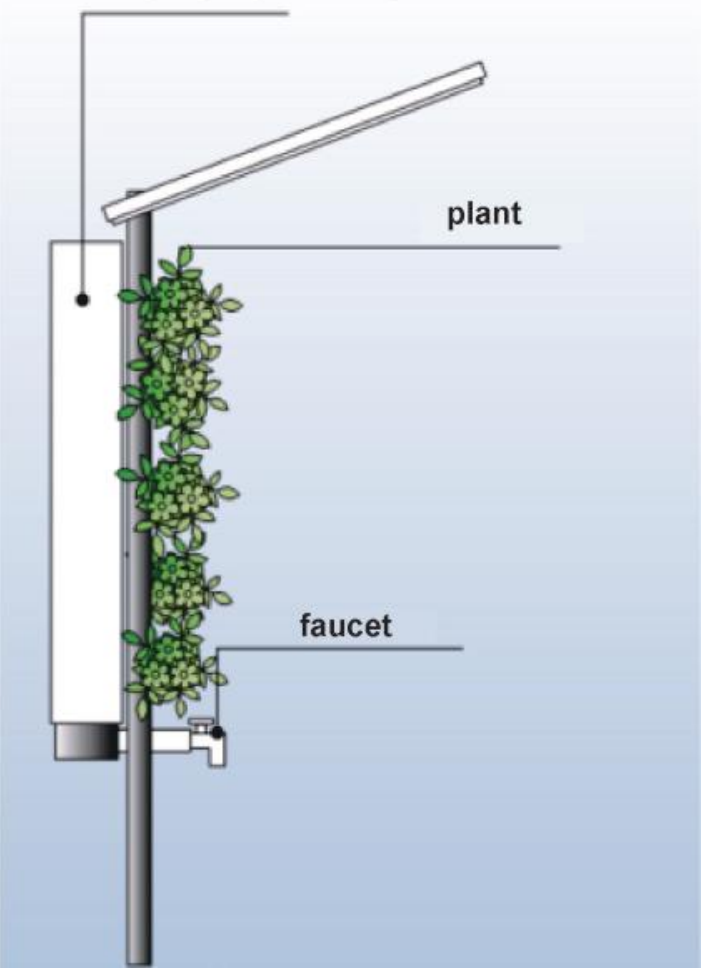

ganic garbage with decomposition system to make it biodegradable also functions as water management by flowing the water to the biopore hole. 
Figure 4. Concept of plants pot in the garbage

(Source: Design of Paryanto, 2012).

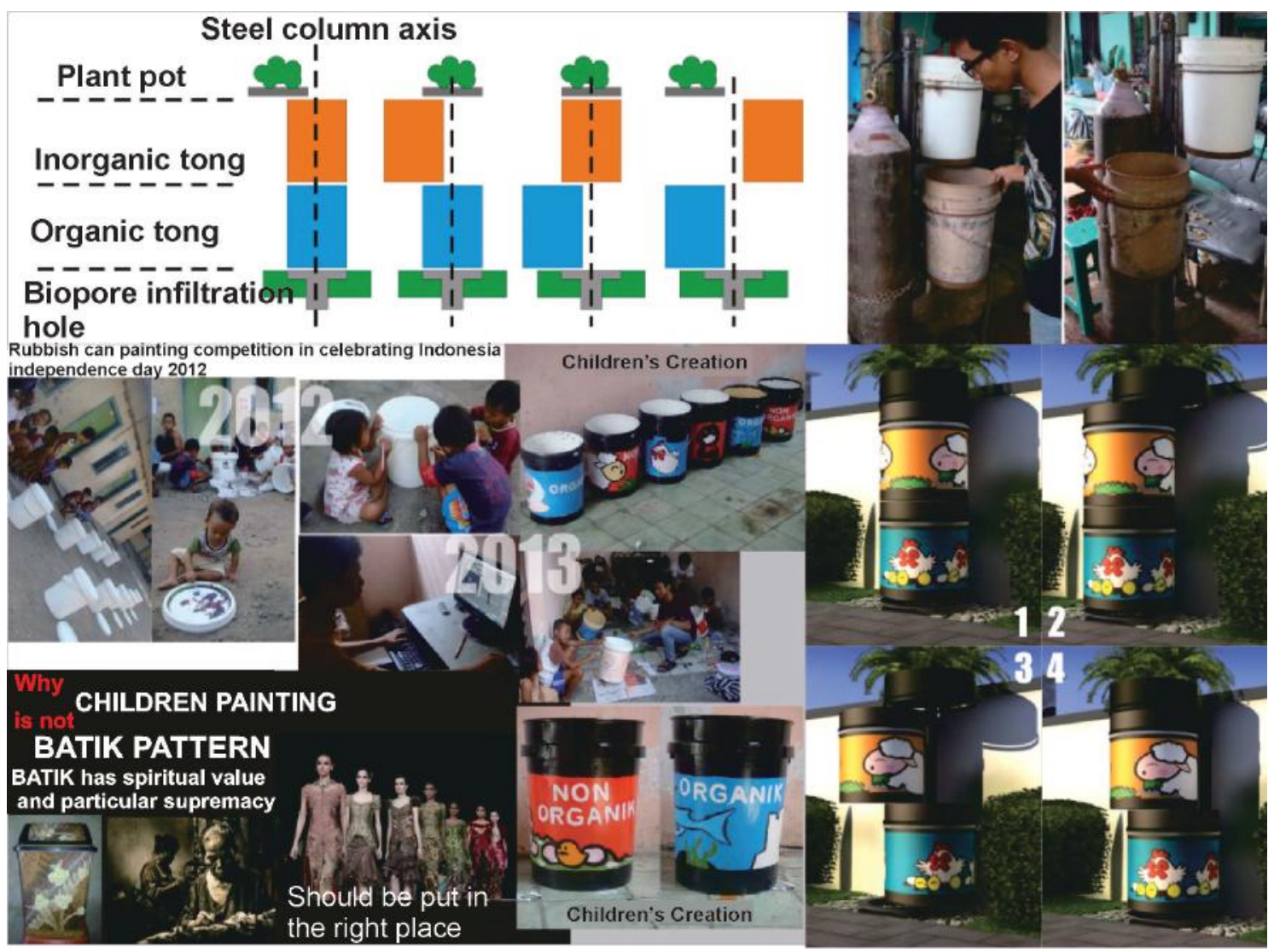

The planning and design of simple building such as residential building in Mojosongo Surakarta can implement energy management both for illumination and for air conditioning as follows:

1. Illumination

Optimization of natural illumination is influenced by the quantity and the quality of adequate illumination to fulfill the need of visual activities. The natural illumination is optimum at $7 \mathrm{am}$ in the morning up to $4 \mathrm{pm}$ in the afternoon, where much sunshine can enter the rooms. Distributions of light in the room should be spread and it may not cause light contrast that may be disturbing or glaring and cause uncomfortableness or decrease vision or ability to see an object caused by too much luminance leading to too much contrast. Glaring can be classified into two kinds. The first is glaring that cause a person unable to see an object (disability glare) and the second is glaring caused by uncomfortableness to see an object (discomfort glare). The principle of natural illumination is using the sunshine as much as possible, reducing the sun heat as much possible, and preventing overglaring.

Therefore, the utilization of natural illumination can save the consumption of electricity energy. Orientation of the building aims to get the stock of sunshine in which the sun light is in the lowest intensity of radiation based on the cycle of sunrise and sunset, and the sun is in the smallest angle of point drop. Thus, the area will gets more sunlight but the people will not feel hot. With the condition of land not in an ideal condition, the building orientation can be done by extending the opening to allow more lights to enter the room and to reduce room 
limits so that the light can get into rooms in the inner part of the building.

Figure 5. Concept of natural illumination and air conditioning combined with greening using vegetation

(Source: Design of Paryanto, 2015).

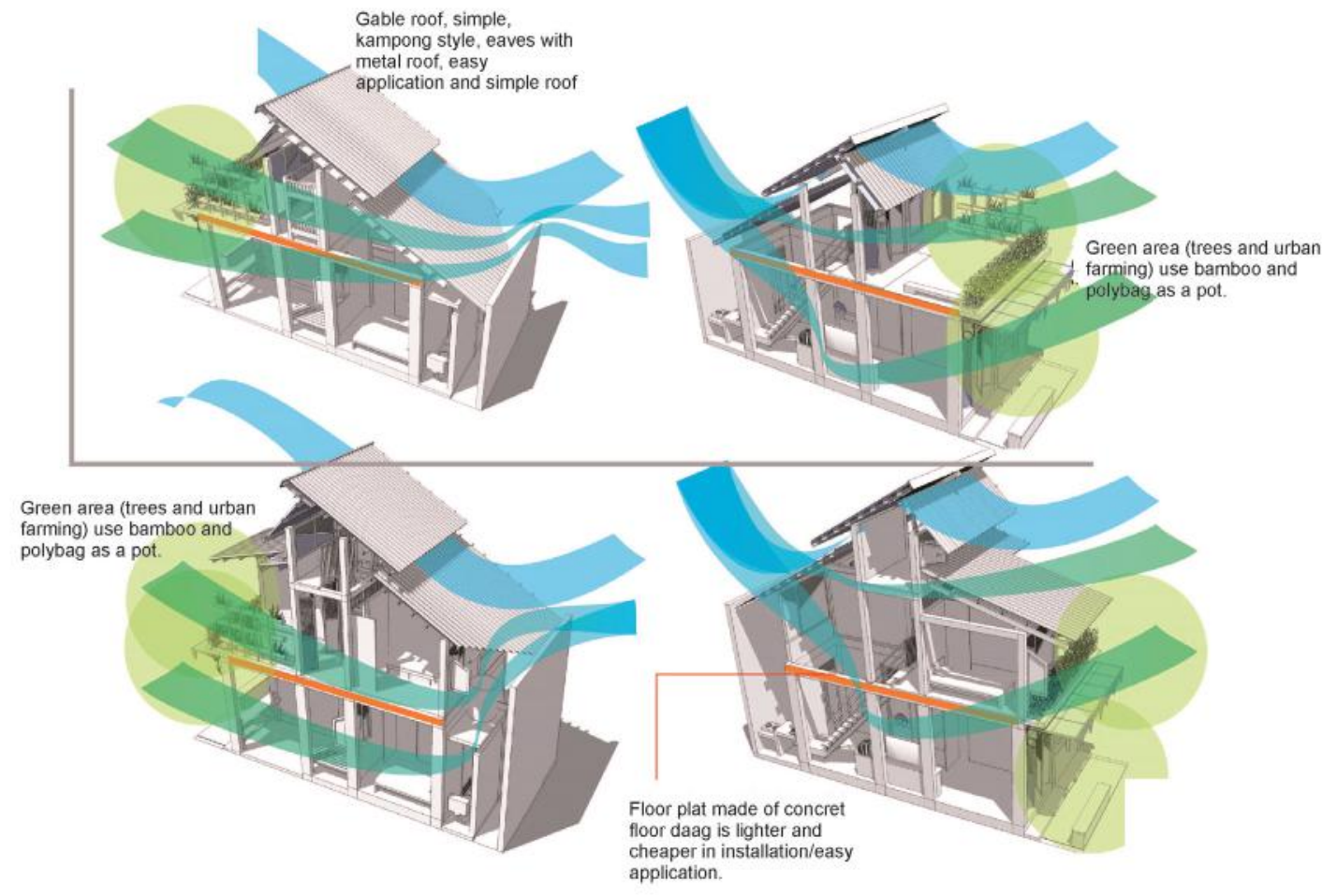

\section{Air Conditioning}

Natural air conditioning can be done by using ventilation and opening, cross conditioning, and other innovative ways. To achieve energy saving for air conditioning can be done by using natural air conditioning, reducing artificial air conditioning and using ventilation and opening or cross air conditioning.

Figure 6. Concept of Building with gabble roof made of metal material ( Source: Design of Paryanto, 2015)

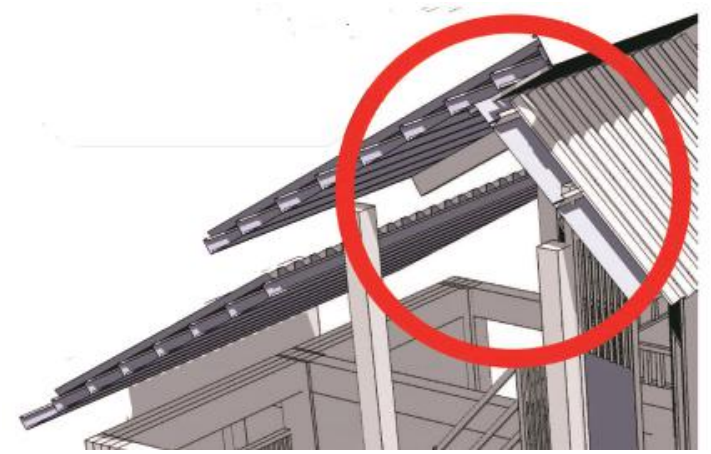

The use of gabble roof structure and roof cover made of metal can be considered in order to have efficient work. Besides having aesthetics, the use of gabble roof with multi levels also functions as wind channel that may make the room cooler. In addition, the heat of metal has been anticipated with heat absorber and the use of ceiling/plafond installed with intermediate space and the roof function as insulator room.

\section{Conclusion}

In the implementation of sustainable architecture, there are some obstacles for optimization because sustainable concept is an interrelated concept between ecological, economics, and social system as well as the preservation of environmental balance. The attributes of green city such as green building in the urban planning is related with the concept of sustainable 
development that supports each other. It is expected that this concept could be the solution in addressing environmental problem in macro and micro level in order to achieve the objectives of sustainable development with the principles of low cost, simple technology, and no impact to the environment in the implementation of sustainable development as consideration.

The concept of sustainable architecture can be adjusted based on various condition and innovation in the implementation of effective technology. Limitation on cost and land will not hamper innovation in realizing sustainable architecture. The innovation can support the effort to achieve green city along with urban planning. Simplicity of design without ignoring the principles of environmental management with the implementation of sustainable architecture can be contributed and developed in various group of communities. A design of simple house including the complementary element such as shelter for plants and recycle bin can be provided to achieve green city through creative design developed by the society. Thus, the government as the urban planner and the motivator of the community should promote about the awareness to preserve the environment to create synergy.

\section{Reference}

Brundtland, Gro Harlem (1987). Our Common Future. World Commission on Environment and Development (WCED). New York: Oxford University Press.

Dyahunique. (2009). Peran Arsitektur dalam dalam Penataan Ruang Kota. http://erbuyu. blogspot.co.id/2009/01/9.html.

Eryudawan, Bambang. (2016) Peran Arsitektur dalam rangka penataan Ruang available at http://erbuyu.blogspot.co.id.
Fisher, Thomas A, AIA. (2002). Sustainable Architecture and Building Design (SABD).

Hui, Sam CM. (2002). Sustainable Architecture and Building Design. www.arch hku.hk/research.beer.htm

Lindfield, Michael and Florian, Steinberg. (2012). Green City. Mandaluyong City, Philippines: Asian Development Bank

Paryanto, DW. (2010). Dwi Wahyu Paryanto, ST. IAI, Desain Rumah Sederhana di Mojosongo Jebres.

Paryanto, DW. (2012). Dwi Wahyu Paryanto, ST. IAI, Desain Pot Tanaman, Tempat Sampah \& Komposter.

Peraturan Daerah Kota Surakarta No. 8 Tahun 2016 Tentang Bangunan Gedung.

Primadella, (2014). Model "Small Building" sebagai salah satu wujud efektifitas ruang dan implementasi arsitektur berkelanjutan, Program Studi Teknik Arsitektur Fakultas Teknik Universitas Sriwijaya.

Priyoga, Iwan. (2010). Jurnal Arsitektur Vol. 8, No.16 2010. Desain Berkelanjutan (Sustainable Design). Universitas Pandanaran.

Register, Richard. (1987). Ecocity Berkeley Building City for Healthier Future. North Atlantic Book, Berkeley, California.

Sukawi (2011). Penerapan konsep sadar energi dalam perancangan arsitektur yang berkelanjutan. Prosiding Seminar Nasional AVoER ke-3 Palembang, 26-27 October 2011.

Steele, James. (1997). Sustainable Architecture. Principles, Paradigms and Case Studies. First Edition. U.S.A : McGraw - Hill Companies, 1997. p. 288. 
Yuliani, Sri (2012). Paradigma Ekologi Arsitektur Sebagai Metode Perancangan Dalam Pembangunan Berkelanjutan Di Indonesia. Sebelas Maret University.

Yunus, M. (2012). Sustainable City Suatu Tantangan Pembangunan. Panduan Pelaksanaan Program Pengembangan Kota Hijau (P2KH) 2011. Jakarta : Direktorat Jenderal Penataan Ruang.
Wikipedia. (2014). Sustainable Design. Retrieved from http://wikipedia.org/wiki/Sustainable_design.

Wildsmith, Diane, (2009), Green Cities Eco Architecture, Symposium on Green Cities , Bogor,Indonesia. 